Article

\title{
Charged Moments: Landscape and the Experience of the Sacred among Catholic Monks in North America
}

\author{
Jason M. Brown \\ Faculty of Environment and Department of Humanities, Simon Fraser University, \\ Burnaby, BC V5A 1S6, Canada; jason.minton.brown@gmail.com
}

Received: 30 November 2018; Accepted: 24 January 2019; Published: 29 January 2019

\begin{abstract}
In light of calls to 're-enchant' the world in the face of our ecological crisis, where do Christians stand on the question of land being sacred? I put this question to monks living at four monastic communities in the American West. For monks living on the land, the world is sacramental of God's presence. However, this sacramental character was not universally recognized as being sacred, or divine. The monastic presence on the land can give places a sacred character through their work and prayer. Far fewer monks admitted that land was intrinsically sacred. However, during what one monk called "charged moments" the sacredness of God was seen as manifesting through the land. Thus, while there is no consensus among monks as to the sacredness of land, there is a deep reverence for place and landscape at the heart of monastic spirituality.
\end{abstract}

Keywords: religion; monasticism; sacred places; landscape; religion and ecology

\section{Introduction}

The March rain was holding off, even as dark clouds threatened, but Brother Salvatore ${ }^{1}$ and I decided to do the interview on foot anyway. We exited the north side of the cloister, and chatted as I adjusted my microphone and clipped it to my left shoulder. We entered the closed-canopy Douglas fir forest that had been planted, maintained, and carefully harvested by the monks of Our Lady of Guadalupe Trappist Abbey since their arrival in Western Oregon in the early 1950s. As we walked, we passed a rather large, quaint, statue of Jesus who stood with open arms at the head of the trail, seeming to welcome us into the woods. We immediately began to climb the steep grade that dominates the eastern half of the property.

Brother Salvatore and I had ambitions to hike to the small brick shrine dedicated to the Virgin of Guadalupe at the very top of the monastery's property. She had been the patroness of the monastery the monks had originally founded in New Mexico, and travelled with them to Oregon when they decided to give up on farming in the desert. Brother Salvatore had a soft demeanor, and a sharp intelligence, and as we walked and talked, he pointed out a section of the trail that he said had always felt particularly sacred to him though he was not sure why. We walked and talked at a moderate pace. When we got winded from climbing the steep slope, we would stop to look up into the canopy, down at a beetle, or muse at a lethargic rough-skinned newt.

On my mind was a line of reasoning within contemporary environmental discourses of the 'Deep' variety. One strategy of cultural shift toward sustainability is the project of "re-enchantment" of the earth as a sacred entity. Under widespread modernism and secularization, the world has lost its mysterious, sacred value and character, and in order to save it, we must look deeper than technological

1 I have used pseudonyms for all of the monks throughout this paper from the novel The Name of the Rose by Umberto Echo. 
fixes, toward a spiritual paradigm shift that revalues the earth as sacred in and of itself. We will not save something we do not love the argument goes, and the effect of this shift will impact how we interact with the earth community. Religion is an ally in this shift, but so too is a broadly defined spiritual ecology movement that blends science, Deep Ecology and ecocentric ethics (Taylor 2009; Curry 2011).

Walking and talking with over 50 monks from four monastic communities located in the American West, I wanted to know how they experienced the sacred. Each community inhabited between 400 and 1300 acres, and each came from a monastic lineage that saw rootedness to place as a central part of their path to God. But was the land sacred? In this essay, I will describe how Roman Catholic monks living in the American West experience land they have taken vows never to leave. My overall project was interested in the meaning and relationality monks develop with place over time. However, in this particular essay I focus on one aspect of this overall interest: how monks responded to the question of whether or not land was sacred. Due to their various theological positions, there is no one monastic approach to sacred place and landscape; reflections are diverse and still evolving. Most of the monks saw land as sacramental of God's creative power rather than sacred in and of itself. Others saw sacredness as a product of their consecrated presence on the land, their work and prayer. However, when the sacred was experienced through land, it often manifested itself at unpredictable times and places, rather than a fixed site or shrine. These 'charged moments', as one monk called them, are a component of the lived, embodied experience of contemporary monastic dwelling, wherein the land participates in the sacred through particular spiritual experiences that reveal God's mysterious presence to the monks.

\section{Methods}

Because of their focus on land-based livelihoods and spirituality, this study focused on Benedictine and Trappist Roman Catholic monastic communities. There are approximately 21 monasteries of these orders living in the American West. The study did not include any Anglican, Carmelite, cloistered Franciscan, Dominican, Brigidtine, Norbertine, Oriental, or Eastern Orthodox communities in order to maintain consistency. I spent approximately 10-15 days as a participant observer/monk at four monastic communities located in the American West and Southwest between December 2015 and April 2016. The monastic communities that participated in this study were: New Camaldoli Hermitage on the Big Sur Coast; Our Lady of Guadalupe Trappist Abbey in Carlton, Oregon; New Clairvaux Trappist Abbey in Vina, California; and, Christ in the Desert Benedictine Abbey in Abiquiu, New Mexico.

The four communities visited in this study were selected based on the criteria that they own and manage land which was in some way integrated into their spirituality or livelihoods. The communities tended to focus primarily on contemplative monasticism, rather than other ministries (also known as apostolates) such as universities, seminaries, or hospitals. None of the monasteries were sought out for a particular approach to land management or environmental focus, however. Recruitment was conducted via email invitation. The four monasteries in this study each responded positively to an invitation to participate in the study. Though I was initially interested in comparing male and female communities, I decided against visiting women's monasteries because of the limitations posed to my primary method of participant observation within such communities.

I conducted walking interviews with voluntary able-bodied participants and the rest were conducted as sitting interviews due to age or time constraints on the part of the monks. I conducted approximately 50 interviews that lasted between 40 and $90 \mathrm{~min}$.

My interview transcripts were then coded using simple categories and subcategories that were anticipated in my research questions, and created based on patterns within the interviews. I paid particular attention to references to the environmental movement, the monastic tradition, biblical and spiritual symbolism, stories and memories, references to work, and moral lessons. For this particular essay, I focused on responses the monks gave to my question of whether or not land was sacred in their theological frame of reference or experience. 


\section{Background: Landscape and the Sacred}

The Latin root for the word sacred is sacrare. In its conventional sense, sacred means to set apart, usually for religious purposes, and emerged from the sacred groves and temple precincts of the cults of the Greek and Roman pantheons. This polytheistic notion that certain deities had dominion over particular areas of land is almost universal among pre-Christian European paganism. In Roman religion, the Genius Loci, or, the 'spirit of the place,' was venerated, consulted, or at the very least revered as an unquestioned reality. Collective associations built shrines or temples to these spirits, and with the rise of the Roman Emperor, the Genius eventually became the protective spirit of the entire Roman Empire (Brisch 2008). Mostly, however, local gods and goddesses were associated with specific places or ecologies such as springs, wells, mountains, groves, the sea, caves, to name only a few sites. In other words, sacredness was located in a particular locale, set apart for religious purposes. However, the sense of these places was not always affection or fondness, but could just as easily be fear, dread, and awe (Tuan 2013).

Asserting that the land is sacred is not as straight forward a task from an orthodox Christian perspective. The heresy of pantheism, in which God is assumed to be the same as or coterminous with the world, has always been a thorn in the side of theologians who wish to keep God and the world at a distance. However, Christianity, especially in its Orthodox and Catholic varieties, has always held certain locations up as sacred or holy. The Holy Land, where Jesus lived and died, particular grottos, wells, mountains, hermitages, or shrines to the saints and their relics are also held to be sacred in their relation to God (Inge 2003).

In the 20th century, however, Christianity has also been at the center of blame for the burgeoning ecological crisis (White 1967). As historian of technology Lynn White Jr. wrote, Christianity's insistence on the separation between God and the world led to the disenchantment of the world, and our ability to see the world as a material object gifted to humanity by God for our well-being.

One proposal for shifting our cultural relationship to the earth has broadly called for the "re-enchantment" of our relationship to the earth, wherein we must reclaim a sense of the earth's sacredness in order to be better motivated to preserve and protect its vulnerable ecosystems. For Sufi activist and spiritual ecologist Llewellyn Vaughan-Lee, the environmental crisis is not a technical problem but a moral-ethical one:

The world is not a problem to be solved; it is a living being to which we belong. The deepest part of our separateness from creation lies in our forgetfulness of its sacred nature, which is also our own sacred nature. We are all part of one, living spiritual being. (Vaughan-Lee 2013, pp. i-ii)

The origins of this process in the West lie with Transcendentalists Ralph Waldo Emerson and Henry David Thoreau, who saw that nature was a kind of material symbol of spiritual truths. Wilderness, places perceived to be devoid of human cultivation and modification then became the new sacred groves (Gatta 2004).

In addition, the spiritual implications of James Lovelock's Gaia Hypothesis, and an increasing commitment to ethical ecocentrism, have continually emphasized the idea that the earth is sacred and that the human attitudes toward her should be one of reverence. Proposed by James Lovelock, the Gaia Hypothesis, after the Greek goddess of the earth, suggested that the earth acts like a super-organism which naturally regulates the planet's conditions so as to maintain optimal conditions for life. While Lovelock himself never proposed that the earth was divine, his ideas quickly spread into more spiritual circles which took up his scientific claims as evidence for more metaphysical or ecospiritual ones (Lovelock 2000; Taylor 2009). For advocates of ecocentrism as a normative ethic, this means that nature is sacred because it is the ultimate source of our value, being, and of life as we know it (Curry 2011). Shifting our understanding toward an earth that is a sacred being to whom we belong could motivate more of us to act in defense of the destruction of the earth and its fragile ecosystems. 
In Christianity, the field of ecotheology has sought to show that while God is ultimately transcendent, God as creator and sustainer of the universe is also immanent to the world. This is assumed based on the Trinitarian nature of God as Father, Son, and Holy Spirit. Building on the incarnational nature of Jesus, theologian Sallie McFague argues that our models for God matter, and that shifting our understanding of God away from a heavenly king would help heal our relationship to the earth. For McFague, the material world can be seen as God's body and thus sacred in and of itself (McFague 1993).

Others have sought to engage the findings of science over the last 200 years as a sacred narrative of its own. Cultural Historian Thomas Berry (1914-2009) has called on Christianity to pay closer attention to the findings of science, so that our universe story can become a kind of sacred myth.

One of the major events in the Christian environmental movement in recent years has been the release in the summer of 2015 by Pope Francis of an Encyclical Letter that addresses environmental issues. Laudato Si: On Case for our Common Home is the most extensive and significant contribution to official Catholic environmental teachings and calls for an "Integral Ecology" in response to climate change and the ecological crisis. Francis uses Catholic social teaching to show that there is an intimate connection between caring for the poor and caring for the earth. In addition, he notes that the earth is not just a means to human ends, but possesses its own dignity and worth independent of its use to human beings (Francis 2015).

In addition to the many essays and defenses being made around Christian ecological theology, the long history of Benedictine monastic spirituality is being retrieved as an example of an alternative approach to the environment by Christianity. For example, in Sara McFarland Taylor's book Green Sisters, she finds that many orders of Catholic Nuns and Sisters are creatively engaging both their own religious traditions and the wider environmental movement by adopting certified organic gardening, erecting green buildings, transitioning to renewable energy, conducting habitat restoration and protection. They are also adapting and experimenting with new liturgical styles and rituals that celebrate the seasons of the year, or the history of the universe as told by science (Taylor 2007).

\section{Findings: Monastic Sacred Place and Landscape}

Speaking with monks about the meaning of sacred, there was, of course, a consensus that God was sacred, or that the Eucharist, the consecrated presence of God in the form of bread and wine consumed during daily Mass, was sacred. In addition, for a majority of the monks I spoke with almost every aspect of land, sky, water, creature, and soil was capable of invoking a spiritual lesson, or was a potential icon of God's presence.

However, to the question of whether or not land is sacred, a majority of the monks felt more comfortable asserting that land was sacramental, rather than itself divine. This means that land as creation can reveal something of God's mark as Creator. None of the monks venerated or worshipped the many beautiful places on their property, and only a few spoke of specific places that were perhaps more sacred than other locales. For a majority of monks, encounters with the sacred were not bounded by certain locales.

Sitting with Brother Ubertino of Christ in the Desert in his office, I asked if he thought the land he lived on was sacred. He sat for a while, and then drew out the question, testing his own assumptions against it, but ultimately not willing to say one way or the other whether the land was sacred in itself:

My hesitation is this. A church is four walls, and it is four walls where we human beings set aside a space to worship God, thus it becomes sacred. One foot outside of the church, is that sacred? Well it could be, but is less so. Anything set apart for God alone, that has the greatest sacral character and so a church is a sacred place, it's a refuge, its sanctuary, Sanctus, you know, holy .... We can take holy things and make them unholy you know, I'm sure plutonium has good uses [laughs]; because it exists, and God created everything. There's not a destructive drug among them, but it's the way we use them. So clearly land has been put to abysmal use, and land has been put to holy use. So is the land sacred? It's nuanced. 
Sacred, in its classical definition is a space that has been dedicated to God. His fellow monk, Brother Malachi, also of Christ in the Desert, spoke excitedly and quickly as we exchanged ideas and thoughts on the banks of the Chama River. He too would take exception with a straightforward land is sacred conclusion:

God isn't imminent in nature; he's ultimately transcendent. He's not incarnate in anything that we see around here, but we believe that the mountains, the grass, the river, everything, is like an icon in that way ... Any sort of natural experience, any sort of experience of natural beauty can be spiritual in that way. It's not God, but it's God who upholds it in being .... . God didn't make you and then leave. God is the reason why you are still alive. God is the reason why everything around us still exists. From the most complicated city down to the simplest ant that's crawling in the grass somewhere ... since God is upholding nature in being at every moment, there is an invitation in nature to see the divine reality that is making all of this possible from moment to moment.

Just as an icon of Christ reveals something of the divine nature because Christ was God incarnate, so creation reveals the love and purposes of God. God is not a distant watchmaker, but intimately involved with all of creation.

Brother Nicolas was also more comfortable with a sacramental sense of land. Walking with Brother Nicolas along the narrow entrance road that leads to the New Camaldoli Hermitage, perched on the tenuous cliffs of the Big Sur coast, we were stopped in our tracks by a small rough-skinned newt that lay motionless in the middle of the driveway. We knelt down to see what she was up to and Brother Nicolas said:

Gosh to me they seem like the world's most vulnerable creatures, just no protection! And they move, you know, anything could squash them [laughs]! I love to see them. There's a beautiful expression ... have you ever heard this? It's credited to Meister Eckhart, 'Every creature is a word of God, and a word from God.' These creatures we see they're just like a little word. What's God saying!?

If creation was a like a book that could be read, creatures were words, and God their author. I asked Brother Nicolas to tell me more and he said,

I believe that creation is sacramental. Reflecting God, conveying God. Somehow speaking of God. Everything kind of showing forth some aspect of God. Maybe the mountains [are] more his strength, and the flowers his delicate beauty ... What is God saying? ... The deer are almost like creatures from another world. They move so delicately and beautifully and they make no noise. They just seem to vanish! They are kind of a reminder of a world beyond this one, and just a plain beautiful thing to see.

The land is not God, the deer is not venerated as divine, or a person, or ancestor spirit, but their existence speaks of God's qualities and purposes. The deer is a reminder both of God's mysterious immanence, and ultimate transcendence; here one moment, and beyond reach the next.

Another set of monks saw sacred as an action, something that the monks do to and with the land where they dwell. Brother Bernardo of New Clairvaux Abbey affirmed that it was in fact the work of the monks that makes the land sacred, rather than some intrinsic property. As we stood in the restored 12th century Chapter Room, I asked Brother Bernardo to talk about how the land contributes to the purpose of monasticism. After discussing the importance of good stewardship, he anticipated my question on whether or not it was sacred:

2 Johannes (Meister) Eckhart (1260-1328) was a German Dominican Priest, theologian, and mystic. 
The community of monks and nuns take the land and make it a sacred space. Of course in terms of creation, God created it so that's why creation itself is sacred, its beauty puts one in touch with God .... we take the property and make it a sacred space ... So in that sense, where the land was supporting the monastery, the monks take the land and make it what it is.

While he flirts with the possibility that the land is beautiful, and that beauty is sacred, ultimately he feels more comfortable with a consecrated view of sacred. Monasteries are consecrated to God, and they do God's work. That work affects the place where they live. Because the monks had been on the land for so long, their prayers had made the land a sacred place.

Brother Berengar from Guadalupe Abbey affirmed this position by suggesting that all the years the monks were present on the land, praying, in fact had changed it:

A community praying in this valley all those years changes the place, I'm convinced of that. People will tell me that when they turn into the place they sense something different. Praying makes a difference, it really does, it changes the environment.

Many of the monks commented on how often retreatants point out just how different their monastery feels from the day-to-day world, that there is something unique about the place. Monks like Brother Bernardo and Berengar would say that this is a result of their presence and prayers on the land.

Consecrating the land to God also influenced the affective atmosphere of the place. This idea often came up when monks cited that there really was a difference between the monastic property and the surrounding landscape. A sacred space is a space devoted to the worship of God. And, in fact, monastic landscapes are devoted to God's purposes through the monastic work, hospitality, and efforts to protect the local ecology.

There was consensus among the monks in every community that caring for the land was their duty. Representatives from each monastery also admitted that the environmental movement had had an influence on how they perceive and care for their properties. As I walked with Brother Salvatore up the steep trail leading to the shrine, he provided me with a thorough historical overview of why some Christians are wary of the term sacred being applied to creation, but also, why others were beginning to embrace it as synonymous with their own sacramental views. When I asked him if he thought of the land as sacred, he reflected a moment and then said:

I've heard it said that from a more animistic or ancient pagan way of looking at nature or creation, you couldn't mess with it, you couldn't alter it too much because everything was 'God-haunted.' I mean there were gods everywhere and spirits, and so you had to be very careful how you related to everything. Well once Christianity became dominant with the sense that creator and creation aren't exactly the same, and there is a transcendence of creator from creation on the one hand, that bestows a different way of looking at God. But also a sense that creation comes from an all-powerful, all-wise artificer.

Brother Salvatore saw the Second Vatican Council of the 1960s as the beginning of an opening of Catholicism in general and his particular monastic community in particular to the wider world, including a more overt affection for nature, evident in the certain wings of the tradition, but de-emphasized in the more austere monastic communities such as the Trappists. He also admitted that the environmental movement had had a real impact on his own thinking about the natural world, and worried about the realities of climate change, pollution, technology, and overconsumption. Using the language of intrinsic value that the environmental movement seeks to engender, Brother Salvatore believes that his own monastery has made significant progress:

I think it has advanced in the sense of both we want to, out of our enlightened self-interest, to maintain the land from generation to generation in good condition for our own welfare; 
but also, that we recognize that it has value in itself, because God made it and loves it. And so it has its own dignity as well ... . So I think we have that sense too; that God is not only the transcendent creator and artificer, but also is here in everything and with everything.

Thus for Brother Salvatore, a sacramental theology rooted in the assumption of God's transcendence of the world is beginning to open to the intrinsic value of creation as rooted in God that might lead him to eventually believe that land is sacred.

Brother Michael from New Camaldoli Hermitage, who was heavily influenced by the California environmental movement, also suggested that land was intrinsically sacred:

The basic creation story: God created creation and declared it good, and we talk of natural revelation. God's love and beauty and wisdom is declared through nature first of all, and then comes a special Christian revelation, [scripture]. But no, nature is sacred in and of itself, and for me in a special way mountains.

To say that nature is sacred in and of itself is to make a metaphysical claim that many of the monks were not comfortable with. While Brother Michael did not grant nature an independent spirit, or godly status, he imbued it with a kind of saintliness. The land comes from God, and at some level actually participates in God.

Theologically speaking, the majority of monks were comfortable in the domain of land's sacramental character; its ability to act as an icon of God's beauty, majesty, and mystery. However, several of the monks, a minority, were willing to characterize this sacramental theology as evidence of land's sacredness.

\section{Charged Moments: Experiencing the Sacred through the Land}

While the question of whether and to what degree land is sacred varied with the monks, all of the monks I spoke with admitted that they had experienced the sacred in some way or another through the place they were living. Whether walking, worshipping, chanting, working, or praying on the land, the sacred often broke through at unexpected moments. So, while much of the literature on sacred landscapes or sacred natural sites is concerned with specific locales, or the ways in which a given cultural or religious group constructs an idea of what is sacred and what is not, within the monastic context experiencing the sacred through the land is not as simple as walking into a shrine or sacred grove.

Praying in the monastic cell, in church, or on the land, engaging in manual work, opens one to God's presence in different modes and avenues, but one cannot simply expect to return to the same place or activity every day and feel the same connection. In other words, while God is understood to be everywhere by the monks, God tends to manifest in particular places or experiences (Inge 2003). The question of sacred landscape is not just a semiotic problem of interpretation, or even of blending of subjective and objective characteristics. It is an event of affective, visceral encounter that can shift and change at unexpected times and places when God bursts forth into the heart or onto the scene unexpectedly and without warning. This could be during a spectacular sunset, or a particularly drab subset, during a long walk on the land, or simply walking from cell to chapel; a particular moment in the Mass, or, while mowing the lawn.

Unlike the bounded, consecrated area of a church, or the domain of an ancient goddess protecting a sacred grove, the simultaneous imminence and transcendence that God holds for the monks can shine through at any given moment. Certainly the monks had their favorite places to pray, think, recreate, walk, and hike, but it was often in unexpected moments or locales that the presence of God was experienced, that the sacred was most intimately felt.

For example, during holy week, Brother William of Guadalupe Abbey noticed three familiar trees silhouetted in the distance, trees that had been there for as long as he could recall, but on that particular day, at that particular time touched him profoundly. He said that their symbolism was "a really charged moment." Perhaps during other times of the year, the trees might not have spoken so 
powerfully, but at that time and in that place, they did. These charged moments bring together inner and outer landscapes and give one a sense of sacredness.

Brother Alinardo of Guadalupe Abbey had a deep gratitude for the profound impact the place had had on his soul, not only through his formation years, during the liturgy and work hours, but through those mysterious moments of encounter that could not be repeated:

I've been blessed, where I've been to a lot of different parts of the country and backpacked and gotten to beautiful spots in nature, so I really do appreciate those moments, but the deeper moment of what the land has meant to me is more of a mystery. Where you're on a hike and it's like somehow God touches you in the hike in this particular spot and you can't repeat it. You go back there it's not going to be the same as when God touched you in that spot, but the memory is there.

Beauty was very important to Brother Alinardo, but the most profound moments on the land were those that could not be repeated. Brother Berengar shared this experience with me about a kind of epiphany moment, where God was revealed in the most familiar of places:

One experience I do remember was with Brother John; we had to make a book run ${ }^{3}$ into Lynnfield College in McMinnville, and it was late afternoon, it was in December and we were driving back and it was dusk, and you could see where on Abbey Road before you turn into the drive way coming close to the turnoff, I could see the ridge, this ridge behind the Abbey [pointing]. And it was just palpable, it just spoke to me of God. You know Edith Stein, when she went to Paris she said 'there's a there.' So, to me it was like it was palpable, there was a silhouette up against the sky, it was dusk, winter day, and I'll never forget that. It was just very consoling. Like, God's behind all of this ... I'd seen that ridge many times so you can't make it happen, so my experience of God is that God hits you from the side, surprises you.

The sacramental character of the world provided a doorway through which the monks sought entry, but the door opens from the inside. The affective qualities of landscape are co-constituted, but that constitution is not a formula. The metaphysical commitment of the monks to the reality of God ultimately speaks to these 'charged moments' and the sacredness of the landscape becomes contingent upon the sacredness of the moment.

While these experiences were often reported to me after the fact, in one instance, I was present for a moment of such transcendent beauty, that made both the monk I was interviewing and I stop and stare for several minutes before speaking again. This happened during my interview with Brother Adelmo. We decided to have a seat on a bench on the outskirts of New Clairvaux's Abbey cemetery, which was lined on two sides by Italian Cypress trees that used to form a cross, until several of the trees were killed by disease. The weather was clear, but the air was still chilly with morning moisture, and I shivered a little until the sun rose above the trees' canopy. Soft-spoken and insightful, Brother Adelmo responded to each of my questions, and as we neared the end of the interview, I stiffened my back to stretch. Out of the corner of my eye I saw that the pollen that had been wafting from the cypress trees all morning had caught the sunlight as it was now rising over the Abbey church, and we were suddenly in the midst of a transcendent display of light that danced in rays through the thick cypress pollen behind a massive cross at the center of the cemetery. It was beautiful, and we both simply paused and watched the display in silence. As I sat watching the pollen dance in the morning sunlight, the cemetery cross took on its full visual potential as a symbol of resurrection, life and light. This 'charged moment' burst through the surface of the everyday in a display of beauty that held Brother Adelmo and I in speechless silence for several minutes. When the pollen diminished and the sun shifted its position, we resumed our interview. 


\section{Conclusions}

Brother Salvatore and I never made it to the Shrine at the top of the ridge. We had to turn back about halfway into the interview in order to return in time for the afternoon prayer of Vespers. Our slow pace and our frequent stops kept us from reaching the top, and as we walked back, the structure of conversation wandered away from my research into more personal and general topics. As we descended past the Jesus statue once again, I was reminded of just how deeply many of the monks see Christ in the land; not necessarily as a quaint smiling man, but as God's cosmic and mysterious presence in and love for the world. And even though most would not say that the land is Christ, there were hints and whispers of his presence everywhere, if one is willing to stop and look.

Funding: This research was funded as part of my dissertation Research at the University of British Columbia, Vancouver. I received a four-year International Student Fellowship from the University of British Columbia. The Ethics review of this project was conducted through the UBC Behavioral Research Ethics Board, under the project title "Dwelling in the Wilderness," Certificate Number H14-02005.

Acknowledgments: I would like to thank the monastic communities that participated in this study.

Conflicts of Interest: The author declares no conflict of interest.

\section{References}

Brisch, Nicole. 2008. Religion and Power: Divine Kingship in the Ancient World and Beyond. Chicago: The Oriental Institute of the University of Chicago.

Curry, Patrick. 2011. Ecological Ethics. Cambridge: Polity Press.

Francis, Pope. 2015. Laudato Si: On Care for our Common Home. Vatican City: Vatican Press.

Gatta, John. 2004. Making Nature Sacred: Literature, Religion, and Environment in America from the Puritans to the Present. New York: Oxford University Press.

Inge, John. 2003. A Christian Theology of Place. New York: Routledge.

Lovelock, James. 2000. Gaia: A New Look at Life on Earth. New York: Oxford University Press.

McFague, Sallie. 1993. The Body of God: An Ecological Theology. Minneapolis: Augsburg Fortress.

Taylor, Sara McFarland. 2007. Green Sisters: A Spiritual Ecology. Cambridge: Harvard University Press.

Taylor, Bron. 2009. Dark Green Religion: Nature Spirituality and the Planetary Future. Berkeley: University of California Press.

Tuan, Yi-Fu. 2013. Landscapes of Fear. New York: Pantheon.

Vaughan-Lee, Llewellyn. 2013. Spiritual Ecology: The Cry of the Earth. Inverness: The Golden Sufi Center. White, Lynn, Jr. 1967. The Historical Roots of our Ecologic Crisis. Science 155: 1203-7. [CrossRef] [PubMed]

(C) 2019 by the author. Licensee MDPI, Basel, Switzerland. This article is an open access article distributed under the terms and conditions of the Creative Commons Attribution (CC BY) license (http:/ / creativecommons.org/licenses/by/4.0/). 